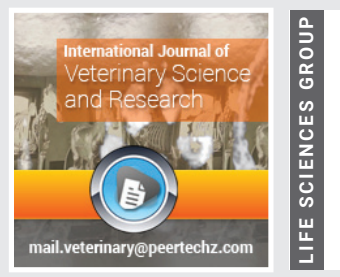

\title{
Epidemiology and economic
} loss of coenurosis in small Ruminants slaughtered at mojo halal export abattoir, Oromia reginal state, East Shoa Zone, Ethiopia

Received: 22 September, 2021

Accepted: 18 October, 2021

Published: 20 October, 2021

*Corresponding author: Sagni Diba, Veterinary Medicine, Ministry of Agriculture, Ethiopia, Tel: +251921180478; E-mail: segni.diba2007@gmail.com ORCID: https://orcid.org/0000-0002-7061-0846

Keywords: Cestodes; Coenurosis; Epidemiology; Goats; Sheep; T. multiceps

Copyright: (c) 2021 Diba S, et al. This is an openaccess article distributed under the terms of the Creative Commons Attribution License, which permits unrestricted use, distribution, and reproduction in any medium, provided the original author and source are credited.

https://www.peertechzpublications.com

Check for updates

\section{Sagni Diba* and Abebe Garoma}

Veterinary Medicine, Ministry of Agriculture, Ethiopia

\begin{abstract}
Coenurosis is an important parasitic disease affecting small ruminant's production which causes significant economic losses. A cross-sectional study was carried out from November, 2019 to May, 2020. To estimating the prevalence of coenurosis in small ruminants and determines the risk factors, to assess the community knowledge on the epidemiology of coenurosis and estimate the financial loss due to brain condemnation. A total 674 small ruminants were by a simple random sampling procedure. Data was analyzed using STATA version 11. Chi square test and logistic regression analysis were used to determine the association between prevalence of coenurosis and potential risk factors. From the total 512 goat and 162 sheep examined for coenurosis $6.02 \%$ and $8.6 \%$ were found positive respectively. There was significance difference between the risk factors and coenurosis infection. More coenurosis infected small ruminants were found in highland $9.7 \%$ (Odd ratio= $2.31,95 \%$ Confidence Interval: $1.14,4.64 ; \mathrm{P}=0.017)$ than midland and lowland. There was high prevalence of coenurois in adult than young age of small ruminants. From 45 positive cysts were examined to identify fertility and viability by using cyst viability and fertility procedure, $17.8 \%$ calcified, $68.9 \%$ sterile and $13.3 \%$ fertile. The diameter of positive cysts showed $46.7 \%, 42.3 \%, 11 \%$ small, medium and large respectively. From 100 respondents' $86 \%$ of respondents has agreed on the sign of coenurosis, $14 \%$ has not agreed. The annual financial losses due to brain condemnation were estimated at 124,821 dollar.
\end{abstract}

\section{Intrduction}

Ethiopia's estimated livestock population is often said to be the largest in Africa. In the country, there were approximately 60.39 million cattle, 31.3 million sheep, 32.74 million goats, 0.46 million camels and 56.06 million poultry [1]. Ethiopia has great livestock potential, but it is not properly exploited due to several factors such as poor management system, unimproved genetic potential, inappropriate disease control policy and lack of veterinary services [2]. Among livestock population small ruminants are important domestic animals in the country. Sheep and Goat production enterprises are very attractive, high contribution of meat and generate cash income from export of meat, edible organs and skin, also they are adaptable to abroad range of environments, have short generation cycles and high production rate [3].
Helminth parasites confronted with challenges in developing country of an ever-rising human population and food shortage, such enormous economic losses caused by the silent predators are intolerable [4]. These diseases are also known to cause public health problems as humans can be infected from accidental ingestion of parasite eggs/larvae passed into the environment with feces from definitive hosts $[5,6]$. Under helminth parasite Cestodes, of the family Taeniidae which infest the dogs (definitive host) are intermediate host species where they cause Coenurosis, Hydatidosis, and Cysticercosis [7].

From cestode parasite coenurosis is problem of small ruminant's production in Ethiopia [8]. It is the larval stages of Taenia multiceps cause both public health due to accidental ingestion of parasite eggs or larvae and veterinary significance 
because they cause economic loss due to condemnations of infected brain [9]. Coenurosis is the stage of Taenia multiceps always develops in the brain of small ruminant's population [10]. The disease is much more common in rural areas of Ethiopia where dogs and domestic animals live in a very close association. Additionally, where home slaughtering of small ruminants is still predominant and uncooked offal and carcass wastes are normally given for dogs [11].

The prevalence of the disease was reported in different area of the country: $3.78 \%, 4.7 \%, 7.6 \%, 12.5 \%, 13.5 \%, 16.6 \%$ and $20.2 \%$. The main source for infection of coenurosis is from maintaining the parasitosis in nature, access by dogs to the brains of dead or slaughtered sheep and goat that were infected with coenuri. Domestic and wild canids such as dog, fox, wolf and jackals are the reservoirs for parasite and shepherded dogs, owner of animals, agro ecology, cyst of prasite, source of infections and transmissions of parasite considered as a risk factor of the disease in sheep and goats [12]. Coenurosis due to ingestion of larval stages of Taenia multiceps can occur in both an acute and chronic disease form. Acute case it occurs during the migratory phase of disease, usually 10 days after ingestion of the large number of tape worm eggs. Young lambs aged 6-8 weeks are most likely to show signs of acute disease [13]. The signs are associated with an inflammatory and allergic reaction. There is transient pyrexia and relatively mild neurological signs such as listlessness and a slight head aversion. Occasionally the signs are more severe and the animals may develop encephalitis, convulse and die within 4-5days [14].

Coenurosis is diagnosed based on epidemiology, clinical sign and post mortem findings. It is more complicated and severe when the oncospheres settle in the CNS tissue. Recently a best technique used for diagnosed the disease is Computed Tomography (CT). It allowed precise evaluation of the size and location of the cyst, which appeared as a hypo attenuating structure is a mass effect [15]. Coenurosis may be found upon necropsy in the brain of sheep and goat but the condition needs to be differentiated from other local space occupying lesions of the cranial cavity and spinal cord including abscess and tumor [16]. The common and widely applied treatment for this disease is surgical removal of the cysts under general anesthesia of the animal, the approach has a very good success rate, especially when the lesion is accurately located [17]. The important control method of the disease are; To prevent dogs from ingestion of uncooked offal, keeping the dog health service, prevent backyard slaughtering and disposal of heads of small ruminants, community education about spread and causes of disease and to giving recommendation on the epidemiology of the disease [18]. Coenurosis is an economically important disease as it causes serious problems especially in the sheep and Goat industry and breeding. It has $100 \%$ mortality rate which cause severe economic losses in small ruminants [19].

In developing countries like Ethiopia there is close contact between dogs and small ruminants, lack of knowledge of the population on epidemiology of coenurosis, free access of dogs to the head of ruminants, containing coenurosis vesicles, the absence of regular deworming of dogs are the most important drivers for perpetuation of T. multiceps cycle and the persistence of coenurosis that leads to high economic losses of the country [12]. The disease cause major economic losses due to decreasing production, mortality rate which treatments cost, brain condemnation, time and loss of energy to keeping sick animals [20].

Human infection occurs if eggs are accidentally ingested as result of poor personal hygiene after being shed in the faces of the dog. After ingestion of the eggs, larvae hatch, penetrate the intestinal wall and migrate to various tissues, where they develop in to large, cystic larvae. Symptoms are secondary to the presence of a cyst in a vital structure [10].

Losses occur when farmers not succeed in animal production because of Coenurosis regularly and decisively lead to the list of parasite infection [21-23]. Recently, in Ethiopia there is a paucity of information and comprehensive study is not available on epidemiological study of the disease. In addition significance of coenurosis in small ruminants slaughtered for export purpose at newly emerging export abattoirs is not studied in detail. Similarly, there is lack of recent information on Coenurosis in study area.

This area is known for its commercial, domestic and export abattoirs established currently.

\section{Therefore, the objectives of this research were}

- To estimate the current prevalence and determine the risk factors of Coenurosis in small ruminants slaughtered at Halal Export Abattoir.

- To assess the community knowledge on the epidemiology of coenurosis

- To estimate the Financial loss due to brain condemnation by coenurosis in small ruminants slaughtered at Mojo Halal export abattoir

\section{Materials and methods}

\section{Description of study area}

The study was conducted in Halal export abattoir and Mojo town. Mojo is found in the Central Ethiopia, Eastern Shoa zone of the Oromia region. This town exists at latitude and longitude of $8^{\circ} \mathrm{N} 39^{\circ} \mathrm{E}$ with an elevation between 1788 and $1825 \mathrm{~m}$ above the sea level. The abattoir is specialist's abattoir for the export of Fresh, Hygienic, Organic and Quality Chilled mutton. It is located in Lumee Woreda, Oromia regional state, East shoa zone, $73 \mathrm{~km}$ east of Addis Ababa. This location enables livestock to be easily sourced as the abattoirs is placed in the vicinity of Goat Sheep and Cattle grazing areas. All the animals slaughtered at HEA are strictly Sharia compliance under the supervision of Supreme council for Islamic affairs, Oromia, Ethiopia and expert veterinarians. All product processed at the abattoir is exported to various locations around the Middle East. All meat and meat product shipments are accompanied by international sanitary certificates issued by the veterinary authorities of the Ministry of Agriculture (Figure 1). 


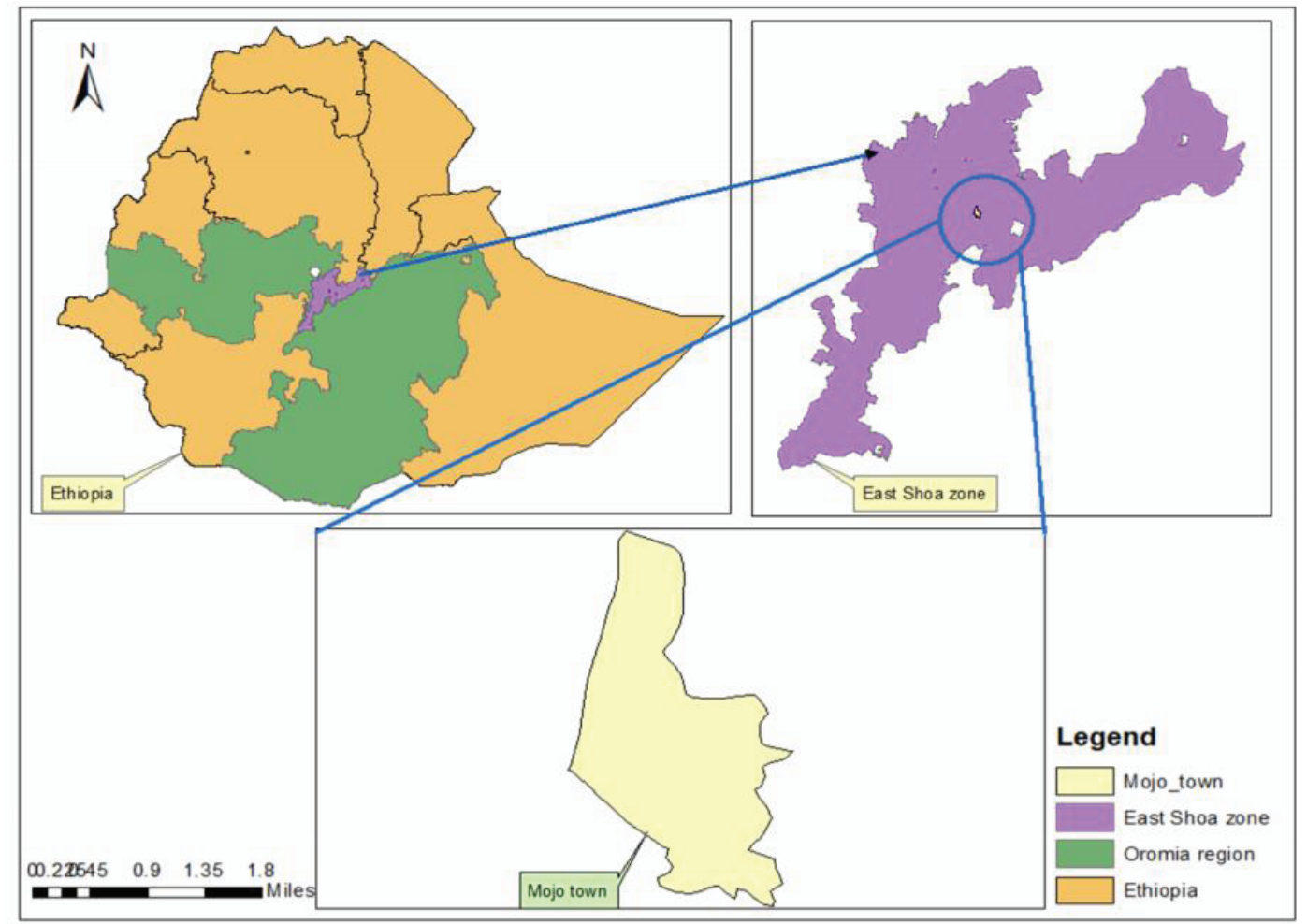

Figure 1: Map of study area.

\section{Study animals}

All local breed's sheep and goats that originated from high land, midland and low land area of country for slaughter in Halal export abattoir were included in the study population. Consequently, all male sheep and goats were subjected for the study by simple random sampling technique which sampling and age of the animals were grouped based on dentition, for those which have not erupted permanent incisor teeth, are classified as young, while those with pair or more permanent incisor teeth erupted were classified as adult [24].

\section{Study design and sample size}

A cross-sectional study type was carried out from December, 2019 to May, 2020. By using simple random sampling technique, the total numbers of animals required for the study were calculating based on the formula given by Thrusfield, (2005). $n=1.96^{2} \mathrm{P}_{\exp }\left(1-\mathrm{P}_{\exp }\right) / \mathrm{d}^{2}$, where $\mathrm{n}=$ required sample size, $\mathrm{P}_{\text {exp }}=$ expected prevalence, $\mathrm{d}=$ Absolute precision. Previously the prevalence study conducted in deferent area of the country, but the agro ecology of previous study and these studies is not same, because of that to take $50 \%$ of expected prevalence. Using $5 \%$ degree of absolute precision, 384 animals need to be sampled. For this study, the required sample size was 384 , but in order to increase precision, it was maximized to 674 (512 Goats and 162 Sheep) sample size.

\section{Study methods}

Abattoir survey: Active abattoir surveys were conducted on sheep and goat before animals was slaughtered based on simple random sampling technique. During ante-mortem examination of each study animal were given an identification number based on species of animals ( 512 goat and 162 sheep), age, weight of animals, body condition, farming system, month of animals slaughtered, agro-ecology was recorded. During study period the sampled animals was classified three times for identify the monthly change of the cyst of parasite based on availability of animals. The first time 250 (200 goat and 50 sheep) were sampled. Second 200(150goat and 50sheep) were sampled and thirdly 224(162 goat and 62sheep) were sampled.

Brain examination: The heads of slaughtered sheep and goats was collected, followed by skin removal and careful opening of the skull using a machete without damaging brain. Meninges were incised using a scalpel blade to expose brain tissue. Whole brain of individual animal was collected and examined for the fertility and viability cyst in parasitological laboratory.

Cyst fertility and viability test: All the positive samples were transported to Halal export abattoir laboratory for confirmation of cyst fertility and viability. After individual cysts were examined grossly for calcification and degeneration, size of cysts was measured. The surfaces of each cyst were sterilized with alcoholic iodine solution. To reduce intracystic pressure was penetrated with scalpel and scissors then the content to be transferred to sterile container. Then examine contents under microscope $(40 \mathrm{X})$ for the presence of protoscoleces into the cyst [25]. The cysts which contain no protoscoleces were sterile cyst. Similarly, viability of the protoscoleces was assessed by motility of flame cells as well as ease of staining with $0.1 \%$ aqueous eosin solution and examination under light microscope. Lived of protoscoleces did not take the dye whereas; the dead ones stained with the dye [26]. 


\section{Questionnaire survey}

To determine farmers and abattoir workers knowledge on the epidemiology of coenurosis open stionnaire were administered. Two Keble's (kolba and shela kiltu) were selected where export abattoir exists and to sell positive brain which containing cyst for the community those lives those Keble's. The selection criteria of an interview for farmers depended on owning $\operatorname{dog}(\mathrm{s})$ and back yard slaughtering system. A total of100 (80 farmers and 20 abattoir) were interviewed randomly to assess knowledge based the formula recommended by Arsham [27]. $\left.\mathrm{N}=0.25 / \mathrm{SE}^{2}, \mathrm{~S} E=5 \%\right), \mathrm{N}=100$, Where $\mathrm{N}=$ sample size, SE=standard error assuming the standard error of $5 \%$ and the confidence interval of $95 \%$. The sample sizes for the questionnaire survey were expected to be 100 (50 Shelakiltu and 50 Kolba) Kebles. The results were expected to generate information on the community and abattoir workers knowledge on the epidemiology of coenurosis.

\section{Assessment of direct economic loss}

The direct economic losses from international markets due to brain condemnation of small ruminants with Coenurosis cysts in Halal export abattoir were estimated by adopting the formula [28]. During estimate direct economic loss assessment to take the average of five year of animals slaughtered in the abattoir and to estimate the finical loss [23].

$\mathrm{EL}=\mathrm{Srx} * \operatorname{Coy} * \operatorname{Roz}$

Where,

EL- Estimated annual economic loss of the brain from

Domestic or international market due to coenurosis,

Srx- Annual sheep and goats slaughter rate of the abattoir,

Coy- Average cost of the brains in the abattoir,

Roz - Condemnation rates of sheep and goats brain

\section{Data management and analysis}

Thedatagenerated werestoredinMicrosoftexcel spreadsheet and analyzed using STATA version 11.0. Percentage, chi square test, univariable logistic regression analysis were performed, to quantify the association between risk factors and coenurosis and odds ratios (OR) and 95\% confidence intervals (CI 95\%) were used to quantify the degree of association between risk factors and coenurosis. These variables were categorized during data analysis. The categories of the variables were as follows: Species of animals (sheep vs. Goat), agro ecology (highland Vs. midland Vs. lowland), age (adult Vs. young), farming system (extensive Vs. semi intensive), body condition (good Vs. lean Vs. medium), and month of slaughtered (December Vs. January Vs. February), weight of animals classified based on criteria of export standard (<18kg Vs. 1822kg VS. >22kg).

\section{Results}

\section{Prevalence of coenurosis}

Out of the total 674 small ruminants examined for the presence of coenurosis an overall prevalence of $6.67 \%$. Out of 512 goats examined for coenurosis $31(6.02 \%)$ were positive.

Similarly, out of the 162 sheep examined 14 (8.6\%) were positive for coenurosis.

\section{Association of risk factors with conurosis infections}

The results of the association of different risk factors with the prevalence of coenurosis using chi square $\left(\mathrm{X}^{2}\right)$ test. Slightly higher prevalence of coenurosis infection was recoreded in sheep than goat. prevalence of coenurosis infection was not significantly associated at species level ( $\mathrm{P}>0.05)$. However coenurosis infection was significantly associated risk factors; age, weight, agro ecology, farming system, body condition and season of animal slaughtered $(\mathrm{p}>0.05)$ as presented in Table 1.

\section{Univariable logistic regression for hypothesized risk factors}

During the Univariable logistic regression analysis, for all the risk factors, the first level of each independent variable (the category of a risk factor with lowest prevalence) was used as a reference Category for measuring the degree of association between the disease and risk factors. Prevalence was $9.7 \%$, $8.2 \%$ and $4.4 \%$ in high land, midland and lowland (Table 2 ).

Table 1: The association between coenurosis prevalence and risk factors

\begin{tabular}{|c|c|c|c|c|c|}
\hline $\begin{array}{c}\text { Risk factors } \\
\text { category }\end{array}$ & no of animals & no of positive & Prevalence (\%) & X2 & p-value \\
\hline \multicolumn{6}{|l|}{ Species } \\
\hline Sheep & 162 & 14 & 8.6 & 1.32 & 0.25 \\
\hline Goat & 512 & 31 & 6 & & \\
\hline \multicolumn{6}{|l|}{ Agro ecology } \\
\hline Lowland & 359 & 16 & 4.4 & 6.15 & 0.017 \\
\hline Midland & 133 & 11 & 8.2 & & \\
\hline Highland & 182 & 18 & 9.8 & & \\
\hline \multicolumn{6}{|l|}{ Age } \\
\hline Young & 361 & 15 & 4.1 & 7.93 & 0.006 \\
\hline Adult & 313 & 30 & 9.5 & & \\
\hline \multicolumn{6}{|l|}{ Wight } \\
\hline$>22 \mathrm{~kg}$ & 126 & 5 & 3.9 & & \\
\hline $18-22 \mathrm{~kg}$ & 314 & 13 & 4.1 & & \\
\hline$<18 \mathrm{~kg}$ & 324 & 37 & 11.5 & & \\
\hline \multicolumn{6}{|l|}{ Farming system } \\
\hline SI & 251 & 8 & 3.1 & 7.81 & 0.007 \\
\hline Extensive & 423 & 37 & 8.7 & & \\
\hline \multicolumn{6}{|l|}{ Body condition } \\
\hline Medium & 522 & 19 & 3.6 & 35.52 & 0 \\
\hline Fat & 89 & 8 & 8.9 & & \\
\hline Lean & 63 & 15 & 23 & & \\
\hline \multicolumn{6}{|l|}{ Month } \\
\hline January & 302 & 15 & 4.9 & 4.83 & 0.039 \\
\hline February & 156 & 9 & 5.7 & & \\
\hline December & 216 & 21 & 9.7 & & \\
\hline
\end{tabular}

Citation: Diba S, Garoma A (2021) Epidemiology and economic loss of coenurosis in small Ruminants slaughtered at mojo halal export abattoir, Oromia reginal state, East Shoa Zone, Ethiopia. Int J Vet Sci Res 7(2): 127-137. DOI: https://dx.doi.org/10.17352/ijvsr.000092 
Univariable logistic regression analysis showed that the risk of infection in highland (OR: 2.31, $95 \%(1.14,4.67)$ higher than midland and lowland. The odd of coenurosis infection in adult was 2.44 times than in young. The odd of coenurosis infection in weight $(<18 \mathrm{~kg})$ was 3.15 higher than $18-22 \mathrm{~kg}$ and $>22 \mathrm{~kg}$ and the Odd of $(18-22 \mathrm{~kg}) 1.04$ times more than in $>22$ $\mathrm{kg}$. The Odd of coenurosis infection based on body condition of animal level lean was 7.1 times than fat and medium and odd of fat was 2.24 times more than in medium. The odd of coenurosis based on farming system extensive was 2.91 times more than in semi intensive. The odd of coenurosis infection based on month of animal slaughtered was in December $9.72 \%$ times than February 2.06 times than December and January and in December 1.1 times than in January. Uni-variable logistic regression analysis also showed that there was a strong association $(\mathrm{OR}>1)$ between positivity and age, weight, agro ecology, farming system, body condition and season of animal slaughtered.

There was no association between species of animals (sheep and goat) $(\mathrm{OR}<1)$ (Table 2$)$.

\section{Cyst characterization}

The predilection sites of positive cyst were $16.7 \%, 66.6 \%$ and $16.7 \%$ right cerebral hemisphere, left cerebral hemisphere and cerebellum respectively. The number of cyst(s) per examined brain ranged from one to three $(1-3)$ and the heads infested by one cyst accounted for $60 \%$ of the total heads. $33 \%$ and $7 \%$ were infested by two and three cysts respectively. Similarly from total forty five positive cysts were recovered, $46.7 \%$, $42.2 \%$ and $11.1 \%$ small, medium and large size respectively. Out of 45 positive cysts were examined to identify cyst calcified, fertility and viability, $17.8 \%, 68.9 \%$ and $13.3 \%$ calcified, sterile and fertile respectively Figure 2 .

\section{Questionnaire survey}

For determination of community knowledge in relation to coenurosis based on personal information a total 100 respondents were received from two Keble were export abattoirs exist and sell to positive brain of small ruminants to community. From two Keble $86 \%$ of respondents agreed the occurrence of the case in small ruminants, but $14 \%$ of respondents not know the case (never see on small ruminants). The result of interview showed $>40$ and $31-40$ age has more agreed on circling than 20-30 age of respondents. The male respondent has more known the sign of the disease than female respondents. Abattoir worker respondent has more known the case than farmer's respondent. Similarly, the result of interview showed Tertiary and secondary level of education has more know the case than Illiterate respondents (Table 3).

Out of the 100 respondents, for identify the farmer and abattoir workers knowledge on cause and mode of transmission of the disease $94 \%$ were totally not know about the cause of coenurosis and the mode of transmission and $6 \%$ of respondents are agreed on the cause and transmission. For identify community knowledge on stage of the coenurosis shows circling $82 \%$ respondents agreed at adult stage and $18 \%$ agreed at young stage of small ruminants. From 100 respondents for awareness of farmer's knowledge on source
Table 2: Univariable logistic regression of hypothesized risk factors for coenurosis in small ruminants at Mojo Halal export abattoir

\begin{tabular}{|l|l|l|l|l|}
\hline Risk factors category & no of animals & Prevalence (\%) & OR $(95 \% \mathrm{Cl})$ & P-value
\end{tabular}

\begin{tabular}{|c|c|c|c|c|}
\hline \multicolumn{5}{|c|}{ Species of animals } \\
\hline Goat & 512 & $6.05 \%$ & 1.00 & \\
\hline Sheep & 162 & $8.64 \%$ & $0.6(0.35,1.31)$ & $P=0.253$ \\
\hline \multicolumn{5}{|l|}{ Agro ecology } \\
\hline Lowland & 359 & $4.4 \%$ & 1.00 & \\
\hline Midland & 133 & $8.2 \%$ & $1.92(0.86,4.25)$ & $P=0.027$ \\
\hline Highland & 182 & $9.7 \%$ & $2.31(1.14,4.67)$ & $P=0.017$ \\
\hline \multicolumn{5}{|l|}{ Age } \\
\hline Young & 361 & $4.1 \%$ & 1.00 & \\
\hline $\begin{array}{c}\text { Adult } \\
\text { Weight }\end{array}$ & 313 & $9.5 \%$ & $2.44(1.29,4.63)$ & $P=0.006$ \\
\hline$>22 \mathrm{~kg}$ & 126 & $3.9 \%$ & 1.00 & \\
\hline $18-22 \mathrm{~kg}$ & 314 & $4.1 \%$ & $1.040 .36,2.99)$ & $P=0.009$ \\
\hline$<18 \mathrm{~kg}$ & 234 & $11.5 \%$ & $3.15(1.18,8.41)$ & $P=0.022$ \\
\hline \multicolumn{5}{|c|}{ Body condition } \\
\hline Medium & 522 & $3.6 \%$ & 1.00 & \\
\hline Fat & 89 & $8.9 \%$ & $2.24(0.96,5.21)$ & $P=0.06$ \\
\hline Lean & 63 & $23 \%$ & $7.1(3.45,14.59)$ & $P=0.000$ \\
\hline \multicolumn{5}{|c|}{ Farming system } \\
\hline SI & 251 & $3.1 \%$ & 1.00 & \\
\hline Extensive & 423 & $8.7 \%$ & $2.91(1.33,6.35)$ & $P=0.007$ \\
\hline \multicolumn{5}{|l|}{ Season } \\
\hline January & 302 & $4.9 \%$ & 1.00 & \\
\hline February & 156 & $5.7 \%$ & $2.06(1.03,4.09)$ & $P=0.039$ \\
\hline December & $\underline{216}$ & $9.7 \%$ & $1.17(0.50,2.74)$ & $P=0.039$ \\
\hline
\end{tabular}

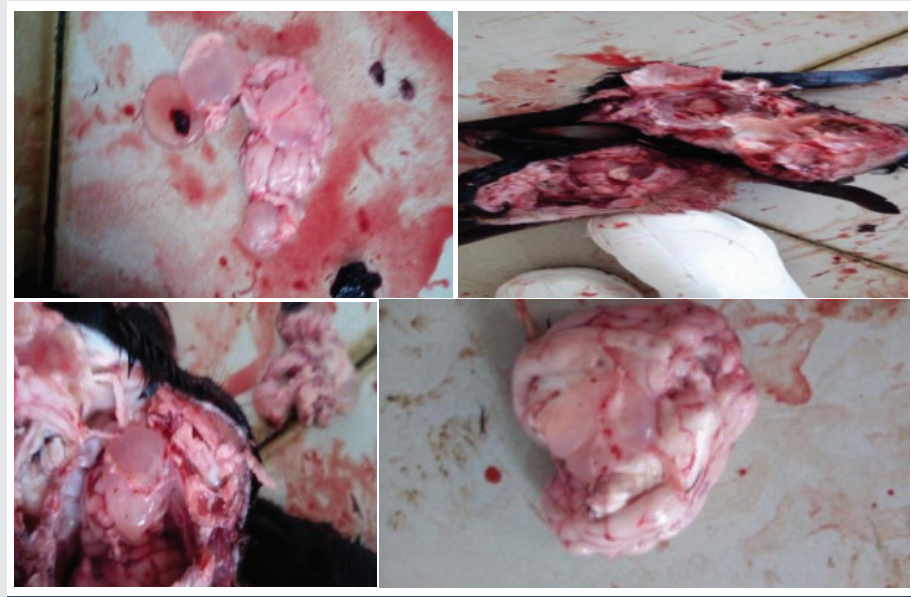

Figure 2: Positive brain containing with coenurosis cysts during sample collection.

of dog food, $100 \%$ respondents agreed the food of dogs from leftover and not agreed on scavengers.

Out of 100 respondents during questionnaire surveys for awareness of farmers knowledge on dog managements $90 \%$ of respondents agreed on free all time and herding and $10 \%$ of respondents agreed on tie at day/night. The result of questionnaire survey found that, the farmers decision for sick small ruminants, $72 \%$ of farmers slaughtered at home, $22 \%$ 
farmers sale at livestock market or butcher and $6 \%$ farmers do nothing sick sheep and goats with coenurosis. Similarly the result of questionnaire found that Ways of disposal system during animals die with counurosis $79 \%$ of respondents throw raw brain to dogs, $21 \%$ throw into bush and not agreed burn, burry and Eaten by family members animals that had died (Table 4).

The wild carnivores particularly stray dogs, hyena and fox which might serve as definitive host for the T. multiceps were seen in different frequencies in the grazing land from questionnaire respondents. The frequencies of stray dogs in the grazing land often greater than hyenas and fox were the occasionally and never in grazing land (Table 5) Figure 3.

\section{Direct financial loss evaluation}

Observation during this study revealed that $14(8.6 \%)$ sheep brain and $31(6.02 \%)$ goat brain were condemned out of the

Table 3: Determination of community knowledge status in relation to coenurosis based on personal information.

\begin{tabular}{|c|c|c|c|c|c|}
\hline \multicolumn{2}{|c|}{ Personal Information } & $\begin{array}{c}\text { No of } \\
\text { Respondent's }\end{array}$ & Knowledge & $\begin{array}{c}\text { Status on circling } \\
(\%)\end{array}$ & P-value \\
\hline \multirow[t]{2}{*}{ PAS } & Shela Kiltu & 50 & $46(92 \%)$ & $4(8 \%)$ & \multirow{2}{*}{0.059} \\
\hline & Kolba & 50 & $40(80 \%)$ & $10(20 \%)$ & \\
\hline \multirow[t]{3}{*}{ Age } & $20-30$ & 55 & $42(76.36 \%)$ & $13(23.63 \%)$ & \multirow{3}{*}{0.07} \\
\hline & $31-40$ & 29 & $27(93.1 \%)$ & $2(6.89 \%)$ & \\
\hline & $>40$ & 16 & $16(100 \%)$ & - & \\
\hline \multirow[t]{2}{*}{ Sex } & Female & 15 & $13(86.66)$ & $2(13.33 \%)$ & \multirow[b]{2}{*}{0.8} \\
\hline & Male & 85 & $72(84.7 \%)$ & $13(15.29 \%)$ & \\
\hline \multicolumn{6}{|c|}{ Occupation } \\
\hline & Farmers & 80 & $65(81.25 \%)$ & $15(18.75 \%)$ & \multirow{2}{*}{0.3} \\
\hline & $\begin{array}{l}\text { Abattoir } \\
\text { worker }\end{array}$ & 20 & $20(100 \%)$ & - & \\
\hline \multicolumn{6}{|c|}{ Educational status } \\
\hline Illiterate & 74 & $62(83.78 \%)$ & \multicolumn{2}{|c|}{$12(16.21 \%)$} & \multirow{3}{*}{0.8} \\
\hline Secondary & 20 & $17(85 \%)$ & \multicolumn{2}{|c|}{$3(15 \%)$} & \\
\hline Tertiary & 6 & $6(100 \%)$ & \multicolumn{2}{|r|}{-} & \\
\hline
\end{tabular}

Table 4: The assessment of community knowledge on epidemiology of coenurosis.

\begin{tabular}{|c|c|c|c|}
\hline Community Knowledge & $\begin{array}{c}\text { Total no. } \\
\text { of respondents }\end{array}$ & yes & no response \\
\hline Knowledge on the reason of cause & 100 & $6 \%$ & $94 \%$ \\
\hline Knowledge on transmission & 100 & $6 \%$ & $94 \%$ \\
\hline Stage of sign occurred & & $\%$ of response \\
\hline Young & 100 & $18 \%$ \\
\hline Adult & 100 & $82 \%$ \\
\hline Source of food for dogs & & \\
\hline Leftover & 100 & $100 \%$ \\
\hline Scavenger & 100 & 0 \\
\hline Dog keeping style & & $90 \%$ \\
\hline Free all-time & 100 & $10 \%$ \\
\hline Tie at day/night & 100 & \\
\hline Sarmers decision for sick animals & & $22 \%$ \\
\hline Sale to market & 100 & $72 \%$ \\
\hline Slaughter at home & 100 & $6 \%$ \\
\hline Do nothing & 100 & - \\
\hline Ways of disposal system & & $79 \%$ \\
\hline Throw to dog & 100 & $21 \%$ \\
\hline Throw to bush & 100 & - \\
\hline Buried & 100 & - \\
\hline Burned & 100 & \\
\hline Eaten by family member & 100 & \\
\hline
\end{tabular}

Table 5: Wild carnivore's information frequency in grazing areas with small ruminants.

\begin{tabular}{|c|c|c|c|}
\hline Wild carnivores information & \multicolumn{3}{|c|}{ Frequency (\%) } \\
\hline & Often & Occasionally & Never \\
\hline Stray dogs & $91 \%$ & $9 \%$ & 0 \\
\hline Fox & $1 \%$ & $9 \%$ & $89 \%$ \\
\hline Hyena & $4 \%$ & $78 \%$ & $18 \%$ \\
\hline
\end{tabular}
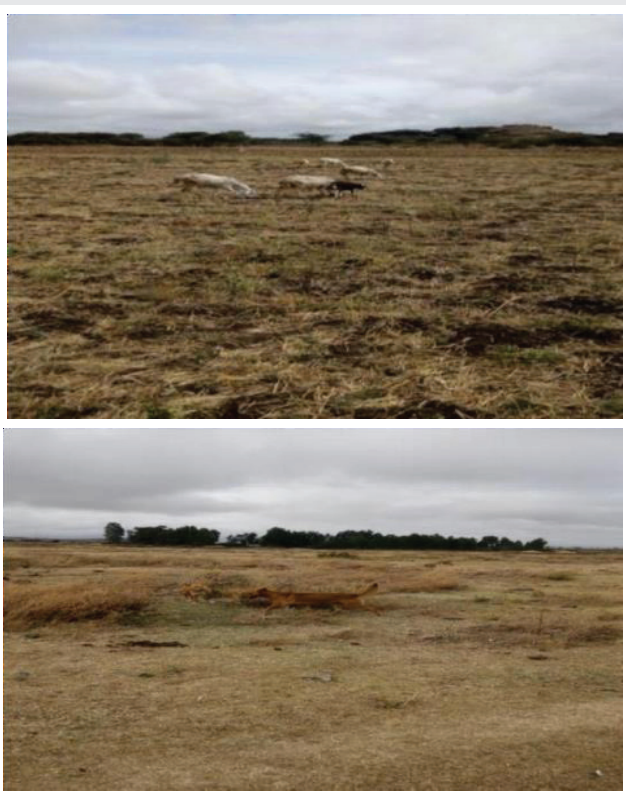

Figure 3: Presence of stray dogs and small ruminants on grazing land.

total infected animals. The average retail market price of sheep and goats brain was 5.75 from international market. Based on these data, average number of animals slaughtered per annum in five year and percentage of brain/animal condemnation per annum were 324,000 and $6.67 \%$, respectively. Therefore, based on the above information, total financial losses due to coenurosis were calculated by using the formula indicated under study design:

$\mathrm{EL}=\Sigma \mathrm{Srx} * \operatorname{Coy} * \mathrm{Roz}=324,000 * 5.75 \$ * 6.67 \%=$ 124,821 SUSD $(3,994,272$ Ethiopia birr).

\section{Discussion}

Coenurosis is known parasite case in Ethiopia especially in the highland part of country were environmental conditions favorable for development cysts of parasite [29,30]. The present study reported an overall prevalence of $6.67 \%$ in small ruminants. Our results are within the range of the prevalence estimated in previous studies in Ethiopia, which ranged from 20.2\% in Debre Berhan [31] and 1.25\% Bishoftu Elfora export abattoir [32] in small ruminants. The overall prevalence higher than the study reported $4.7 \%$ by $[22,31]$ in Ethiopia and lower than study reported $15.5 \%$ [33] in Turkey. The difference of the result might be due to environmental condition which favorable the development of cysts.

The prevalence of coenurosis in this study was relatively lower in goat $(6.02 \%)$ as compared with sheep (8.64\%)which 
is comparable to the Bishoftu Elfora export abattoir $2.6 \%$ in sheep, $1.25 \%$ in goat [32], in Ethiopia, in Iran 9.8\% in sheep [14] and $45.6 \%$ in Tanzania [12]. However, it was higher prevalence in goat than sheep the previous study reported prevalence of $3.9 \%$ in goat and $2.5 \%$ in sheep at Hashim export abattoir [20], $11.7 \%$ in goat and $4.9 \%$ in sheep at Elfora export abattoir [23] and $12.44 \%$ in goat and $2.3 \%$ in sheep at three export abattoir (Elfora, Hashim and Luna) [34] in Ethiopia, in Mozambique $13.8 \%$ in goat [35]. The variation of the result might be due to grazing habit of animals, geographical condition, closely contact between study animals and definitive host of parasite (dogs) and social condition.

The study revealed that the overall prevalence of coenurosis in sheep slaughtered at Halal export abattoir was $8.64 \%$ in sheep which is lower than the prevalence of $20.2 \%$ from Debre Berhan [31], 12.6\% from Bale [36] and Oryan, et al. (1994) in Iran (9.8\% in sheep). However, it was higher than the reported prevalence of $2.5 \%$ reported from Hashim export abattoir [20], 4.7\% from Ethiopian Health institute [22], 4.9\% Bishoftu Elfora export abattoir [23], 2.6\% Bishoftu Elfora export abattoir [32] and 2.3\% in sheep at three export abattoir (Elfora, Hashim and Luna) [34] and Sharma and Chauhan (2006) in Ethiopia ( $5 \%$ in sheep). Similarly prevalence of coenurosis at Halal export abattoir was 6.05 lower in goat than prevalence $11.7 \%$ at Elfora export abattoir [23] and $12.44 \%$ at three export abattoir (Hashim, Elfora and Luna) [34] in goat in Ethiopia 43.3\% in Tanzania [12] in goat, $13.8 \%$ in Mozambique [35] in goat. However it was higher than the reported prevalence $3.9 \%$ at Hashim export abattoir [20] and 1.25\% at Elfora export abattoir [32] in Goat. Variation of the results might be due to different agro ecological condition of animals and presence carnivore's animals which are definitive and final host of coenurosis in grazing land of small ruminants.

The prevalence of study revealed that higher in highland (9.7\%) and midland (8.2\%) than lowland (4.4\%) based on agro ecological condition of study animals. Comparative study was higher than the reported prevalence15.2\% in midland and $11 \%$ in lowland [23]. The great variation might be due to the higher percentages of ecological variables like, rain fall, relative humidity and air temperature are considered to be the influencing factors for coenurosis. In rainy season, rain causes spread of feces of dog, fox (final host) over the grasses and these contaminates are responsible for the increased occurrence of gid during rainy season [37].

Statistically significance showed higher prevalence in adult $(9.5 \%)$ Compared to young small ruminants $(4.1 \%)$ is consistent with earlier studies [23] the result might be due to higher ingestion of cysts with increasing age and the shows the clinical sign after long period of time. Comparative results were reported Higher prevalence of coenuruses was recorded in young $6.8 \%$ animals than adult $1.9 \%$ small ruminants(Worku et al., 2019), 5\% adult [34] and [38] 4\% adult and 5.3\% in adult in different parts of Ethiopia. Previous studies showed that coenurosis in small ruminants is common in young animal $[39,40]$. This higher prevalence in young is most probably attributed to under developed immunity and young animals thus higher infection rate in these animals where as the adults have acquired immunity [41]. The study showed statistical significance higher prevalence in $<18 \mathrm{~kg}(11.5 \%)$ as compared to $18-22 \mathrm{~kg}(4.1 \%)$ and $>22 \mathrm{~kg}(3.9 \%)$ of weight animals was a reason might be attributed large weight herds to getting contaminated region of grazing permanently as result reduction of pastures and shepherd dogs feed large herds in insufficient pastures. On the other hand, the disease may be loss of weight of animals.

The higher prevalence in lean body condition as compared to medium and fat in small ruminants this might be due to the problem of selecting sheep and goat with good body condition from the flock during purchasing as it is confusing due to the presence of wool especially sheep and the apparently health animal was loss there body condition. Statistical significance showed that higher prevalence in extensive management system $(8.7 \%)$ than semi intensive (3.1\%). Monthly prevalence of coenurosis was found $9.7 \%$ in December, $5.7 \%$ in February and $4.9 \%$ January. Comparative study was higher than study reported 3\% December 3.7\% January, 4\% February in small ruminants (Adane et al., 2015). The variation might due to temperature of the months, at high temperatures, cyst of parasite they died in a few hours. The cyst takes approximately eight months to mature, during which it becomes progressively larger, as the volume of cysts fluid increases [42].

The cyst may be localized in any part of the brain more commonly in the cerebral hemisphere (Parihar, 1988) in the present study right cerebral hemisphere $(16.7 \%)$, left cerebral hemisphere $(66.6 \%)$ and cerebellum (16.7\%). This observation shows the high percentage of cyst were located in left part of cerebral hemisphere is higher than the right cerebral hemisphere, the result higher than the study reported by Adem, 2006 (62\% in left, 30\%in right) mengistu, et al. [23] (38\% left and 17\% right) and Adane, et al. [20] (18.3\% left and $10 \%$ right) in Ethiopia. Vink et al., 1997 in Mozambique (62\% in left, 30\%in right), Miran, 2015 in Tanzania(56.1\% Right and $41.5 \%$ in left in sheep and $46.2 \%$ left and $46.2 \%$ right in goat). This difference suggests that there are equal chances of the cyst to lodge at any site of the brain, but the higher percentage of localization of the cysts in the cerebral hemisphere is most probably due to its higher biomass than the other part of brain, and the circling is always from left side to the right [43-55].

All of the 45 positive brains of small ruminants were found to contain only 1 to 3 cysts in each brain Thus, $44.4 \%$ of the positive brains had only one cyst which is lower than Hayelome, 2008 ( $81 \%$ one cyst per brain). The finding shows higher one cyst in each brain than two and three cysts per brain of positive small ruminants findings of the current study agrees with the observation of Achenef, et al. [31], Adem [34] and Hayelome [38,56-89] indifferent parts of Ethiopia (One to three cysts per brain). From 45 positive brains of small ruminants were contain $46.7 \%$ small, $42.2 \%$ medium and $11.1 \%$ large size of cyst. Our overall finding that 45 of coenurus cysts were $17.8 \%$, $68.9 \%$ and $13.3 \%$ calcified, sterile and fertile respectively. The study showed that coenurosis is a well known small ruminant's health problem based on questionnaire survey. From farmers and abattoir workers knowledge where $86 \%$ of respondents 
had seen the disease and $14 \%$ had not seen the disease on small ruminants. However, they have lack of knowledge on the cause and how it is transmitted. Considering the livestock keeping and husbandry that have persisted for several decades in the area, it is not of doubt that farmers aware of livestock diseases that normally prevail within their herds and flocks. The established timeline indicated that respondents from shela kiltu (92\%) and $80 \%$ kolba community respondents known the disease (coenurosis) has been prevalent in their Keble, however $8 \%$ in shela kiltu and $20 \%$ in kolba respondents were not had seen the disease in there Keble. However, there were the same perceptions on when the disease was seen for the first times in two studies Keble's.

The observation shows knowledge of the disease higher $>40(100 \%)$ age of respondents than $2030(76.36 \%)$ age but there was no knowledge on epidemiology of the disease. Similarly the male $(86.6 \%)$ respondents had higher knowledge than the female $(84.7 \%)$ respondents of the disease and the tertiary $(100 \%)$ level of education had higher knowledge than Illiterate $(83.7 \%)$ and primary/secondary (85\%) level of education. allover $100 \%$ respondents indicated that the disease (coenurosis) has been shows the sign at adult stage than young stage of sheep and goats. According to their explanations on the disease magnitude, initially coenurosis shows the sign gradually after same month of animal ingestion the cysts of parasite. Knowledge on cause and the mode of transmission is very important in the control of the disease [18]. It has been found that the coenurosis is maintained by close interactions between the definitive and intermediate hosts (dogs and small ruminants).

This is facilitated by the very limited knowledge on the cause and transmission of coenurosis in study area. It is important that during home slaughters of small ruminants and brain tissues which are seen as not fit for human consumption are simply thrown away into the bush were the grazing land of small ruminants and nearby stray $\operatorname{dog}(\mathrm{s})$ to feed. To thrown brain of small ruminants to dogs actually cultivates the disease problem when they contain an infective material by increasing the risk of small ruminant's infection. The result of questionnaire survey shows absence of community knowledge is increasing the prevalence of disease if definitive host to ingest infected brain which contain Taenia multiceps cyst.

The observation from respondents shows improper disposal of infective brain or throwing into the bush and/or direct feeding brain by dogs, dog management like feeding left over, absence of deworming of dogs by anthelmintics, dog keeping style which is most dogs free all the time and sometime these are shepherd dog that increases the chance of pasture contamination by there faeces. Presence of wild life (stray dogs, fox and hyena) on grazing land of small ruminants frequently, decision of farmers during animals sick (sale to the market, home slaughtering) was seen as an important factor which contributes to the epidemiology of the disease.

The annual estimated financial loss in the present study need to be cautiously interpreted as it would be affected by factors which are dynamic and change over time due to market price of sheep and goat as condemnation of the brain, prevalence of disease and number of animals slaughtered every year which can change the amount of financial loss from year to year. Financial loss analysis due to coenurosis in small ruminant slaughtered, retail price of brain in international market and prevalence of the disease at study time in Halal export abattoir. Based on the information, estimated financial loss due to coenurosis in small ruminants during the study period was 124,821 SUSD $(3,994,272$ ETB) per annum. Financial loss analysis reported by [21-23] mentioned that coenurosis in small ruminants is a major cause for condemnation of brain $(85.7 \%)$ in Ethiopia from apparently healthy slaughtered sheep and goat.

\section{Conclusion and recommendations}

Coenurusis is one of the most important problems of small ruminant's production in developing country including Ethiopia. The study clearly indicated that coenurosis affects small ruminants in study area. According to this study higher prevalence of coenurosis was recorded in animals from highland and midland than those from lowland parts of the country. Similarly the prevalence of coenurosis was also higher in adult than young small ruminants. This suggests coenurosis is responsible for huge economic losses in both sheep and goats production of the country. In appropriate disposal of heads being practiced by the abattoirs can enhance the continuation of the life cycle between the intermediate and final host. Questionnaire survey showed that major factor that plays a great role in the persistence of the disease is mainly human factor that is lack of knowledge on epidemiology of the disease including appropriate control measures.

Based on above conclusion the following recommendations were forwarded:

- Farmers and all community should aware about the danger of feeding uncooked disposal of head for dog and backyard slaughtering of small ruminants

- Level of community knowledge should increasing on the epidemiology of the disease and how it can be prevented

- To interrupt the life cycle of the parasite the carcasses or offal and brains of the intermediate hosts should not given to dogs nor left for wild carnivores.

- The appropriate disposal system of abattoir should practice for condemnation heads of small ruminants.

- Further epidemiological studies should be needed on different region of country.

\section{References}

1. Central Statistical Agency (CSA) (2018) Federal Democratic Republic of Ethiopia Agriculture sample survey, Addis Ababa, Staticall bulletin 2: 583.

2. Ayele S, Assegid W, Belachew H, Jabbar M, Ahmed M (2003) Livestock marketing in Ethiopia: A review of structure, performance and development initiatives. Socioeconomic and Policy Research Working Paper 52. ILRI (International Livestock Research Institute), Addis Ababa, Ethiopia. Link: https://bit.ly/3piiOOi

Citation: Diba S, Garoma A (2021) Epidemiology and economic loss of coenurosis in small Ruminants slaughtered at mojo halal export abattoir, Oromia reginal state, East Shoa Zone, Ethiopia. Int J Vet Sci Res 7(2): 127-137. DOI: https://dx.doi.org/10.17352/ijvsr.000092 
3. Dejene S, Abebe B, Degefu H (2013) Study on the Major Health Problems That Causes Carcass and Organs Condemnation at Hashim's Export Abattoir, Debrezeit, Ethiopia. Global Veterinary 11:362-371. Link: https://bit.ly/3BYD7nn

4. Biffa D, Jobre Y, Chakka $\mathrm{H}$ (2006) Ovine helminthosis, a major health constraint to productivity of sheep in Ethiopia. Animal Health Research Review 7:107118. Link: https://bit.ly/3IUILmc

5. Jenkins D, Romig, T, Thompson R (2005) Emergence/re-emergence of Echinococcus species, a global update. Int J Parasitol 35: 1205-1219. Link: https://bit.ly/3BQDznH

6. Ashrafi K, Valero M, Panova M, Periago M, Massoud J, et al. (2006) Phenotypic analysis of adults of Fasciola hepatica, Fasciola gigantica and intermediate forms from the endemic region of Gilan, Iranian Parasitology International, 55: 249-260. Link : https://bit.ly/3G02aJd

7. Gadahi J, Arshed M, Ali Q, Javaid S, Shah S (2009) Prevalence of gastrointestinal parasites of sheep and goat in and around Rawalpindi and Islamabad, Pakistan. Veterinary World. 2: 51-53. Link : https://bit.ly/3naMjyM

8. Radfar M, Tajalli S, Jalalzadeh M (2005) Prevalence and morphological characterization of Cysticercus tenuicollis (Taenia hydatigena cysticerci) from sheep and goats in Iran. Veterinarski Arhiv 75: 469-476. Link: https://bit.ly/3n78MNf

9. Utulas M, Esatgil D, Tuzer, S (2007) Prevalence of hydatidosis in slaughtered animals in Thrace, Turkey. Parasitology Dergisit 31: 41-45. Link: https://bit.ly/3m4nS77

10. Sharma D, Chauhan $P$ (2006) Coenurosis status in Afro-Asian region: A review Small Ruminants Research 64: 197 - 202. Link: https://bit.ly/3png4PE

11. Fromsa A, Jobre $Y$ (2011) Infection prevalence of hydatidosis (Echinococcus granulosus) in domestic animals in Ethiopia: a synthesis report of previous surveys. Ethiopia Veterinary Journal 15: 11-33. Link: https://bit.ly/3DVgVv0

12. Miran M, Nzalawahe A, Kassuku J, Swai E (2015) Prevalence of coenurosis in sheep and goats at three slaughter slabs in Ngorongoro District, Tanzania. Tropical Animal Health Production 47: 1591-1597. Link: https://bit.ly/3aRKNMj

13. Avcioglu H, Terim K, Yildirim A (2012) Clinical morphological and histopathological features of bovine coenurosis: case reports. Review of Veterinary Medicine 295-298. Link: https://bit.ly/2XtEqM5

14. Oryan A, Goorgipour S, Moazeni M, Shirian S (2012) Abattoir prevalence, organ distribution, public health and economic importance of major metacestodes in sheep, goats and cattle in Fars, southern Iran. Trop Biomed 29: 349-359. Link: https://bit.ly/30JQMkD

15. Godara R, Katoch R, Yadav A, Khajuria J, Borkataki S (2011) Coenurosis in small ruminants: an overview Veterinary Practice 12: 102-105. Link: https://bit.ly/2Zb4U5Y

16. Upadhayay A (2005) Text book of preventive medicine, first edition International, book distributing company 452-454.

17. Scott $P$ (2012) Diagnosis and treatment of coenurosis in sheep, University of Edinburgh, Easter Bush Veterinary Centre, Roslin, Midlothian, Scotland, United Kingdom. Vet Parasitol 189: 75-78. Link: https://bit.ly/30MOCAR

18. Loomu M (2010) Trans-boundary Animal Disease Surveillance in Ngorongoro District: The case of Peste des Petits Ruminants. Research paper for award of MPVM at Sokoine University of Agriculture. Morogoro, Tanzania 37.

19. Kheirandish R, Sami M, Azizi S, Mirzaei M (2012) Prevalence, Predilection sites and pathological findings of Taenia multiceps coenuri in slaughtered goats from south-east Iran. Onderstepoort J Vet Res 79: 1-5. Link: https://bit.ly/3vtEOqn

20. Adane P, Kumsa B, Hiko A, Afera B (2015) Prevalence of Coenurus cerebralis in Small Ruminants Slaughtered at Hashim Export Abattoir, Bishoftu, Oromia. Journal of Europian Applied Science 7: 56-63. Link: https://bit.ly/3BZKfQy
21. Ejeta G, Jibat T, Asfaw Y, Wudie A (2008) Causes of abattoir condemnation in apparently healthy slaughtered sheep and goats at Hashim Nur's Livestock and Meat Export abattoir, Debre Zeit, Ethiopia. Revue de Médical Véterinary. 159: 305-311.

22. Deressa A, Tilahun T, Tadesse A, Beyene M, Gebrewold G, et al. (2012) Assessment of Coenurus cerebralis and its economic impact in sheep brain harvested at Ethiopian Health and Nutrition Research Institute, Ethiopia. International Journal Livestock of Research 2: 217-226. Link: https://bit.ly/30CaVc5

23. Mengistu S, Diba F, Dinaol B, Amare E (2017) Prevalence of Coenurus cerebralis and its Economic Loss in Small Ruminants Slaughtered at Bishoftu Elfora Export Abattoir, Haramaya University, College of Veterinary Medicine, P.O. Box: 138 Dire Dawa, Ethiopia. European Journal of Biological Sciences 9 : 101-105, 2017. Link: https://bit.ly/3aTFr37

24. Alemu Y and Merkel R (2008) Sheep and goats' production, Handbook for Ethiopia 2. Link: https://bit.ly/30C2EF3

25. Daryani A, Aiaei R, Arab R, Sharif M (2006) Prevalence of hydatid cyst in slaughtered animals in Northwest Iran. Journal of Animal Veterinary Advance 5: 330-334. Link: https://bit.ly/3jhVJYh

26. Gracey J, Collins D, Huey R (1999) Meat Hygiene (3rd edition),.W.B. Saunders Company Ltd, USA 669-678.

27. Arsham H (2002) Questionnaire Design and Surveys Sampling, Survey: The Online Survey Tool. Link: https://bit.ly/3vrdE3E

28. Ogunrinade A, Ogunrinade B (1980) Economic importance of fasciolosis in Nigeria. Trop Anim Health Prod 12: 155-160. Link: https://bit.ly/3B4I6D6

29. Njau B, Scholteus R, Kasili O (1990) Parasites of sheep at the International Livestock Centre for Africa, Debre Behan Station, Ethiopia. Preventive Veterinary Medicine 9: 267-277.

30. Bekele T, Woldeab T, Lahour-Kssi A, Sherington J (1992) Factors affecting morbidity and mortality on farm and on station in the Ethiopian highland sheep. Acta Tropical 52: 99-109. Link: https://bit.ly/3jjz2my

31. Achenef M, Markos G, Feseha A, Hibret T, Tembely S (1999) Coenurus cerebralis infection in Ethiopian highland sheep: incidence and observations on pathogenesis and clinical signs. Tropical Animal Health Production 31: 15 24. Link: https://bit.ly/3C20sVa

32. Worku E, Muluneh H, Getahun E, Abaysew A (2019) Prevalence majo metacestodes of ruminant slaughtered at Elfora export abattoir and public health importance. College of Veterinary Medicine and Agriculture, Addis Ababa University, Ethiopia. Link: https://bit.ly/3aWZiP3

33. Gicik Y, Kara M, Arsalan M (2007) Prevalence of Coenuruscerebralisin sheep in Kars Province, Turkey. Bullet, Veterinary Instution Pulawy. 51: 379-382. Link: Link: https://bit.ly/3jjRfjU

34. Adem A (2006) Prevalence of coenurosis at three export abattoir (Hashim Elfora, Luna). A thesis submitted to the school of graduate studies of Addis Ababa University in partial fulfillment for the degree of Master of Science in tropical veterinary medicine 63. (URL).

35. Vink W, Lopes Pereira A, Nota K, De Balogh W (1997) Prevalence of Coenurosis in goats in tete province. Mozambique 72-99.

36. Jawar A (2015) Study on prevalence, associated factors, farmer's perception and economic importance of coenurus cerbrallis in sheep and goats in and around Lega Hida district of Bale zone, Jimma University, college of agriculture and veterinary medicine, school of veterinary medicine, DVM thesis, 34

37. Hashim M, Rashid M, Nooruddin M (2000) Extraneural coenuriasis in Bengal goats. 4. Treatment. Bangladesh Veterinary 17: 46-49. Link: https://bit.ly/3n9lSd1

38. Hayelome M (2008) A thesis submitted to the faculty of veterinary medicine

Citation: Diba S, Garoma A (2021) Epidemiology and economic loss of coenurosis in small Ruminants slaughtered at mojo halal export abattoir, Oromia reginal state, East Shoa Zone, Ethiopia. Int J Vet Sci Res 7(2): 127-137. DOI: https://dx.doi.org/10.17352/ijvsr.000092 
Haramaya University in the partial fulfillment for the requirements for the attainment of the degree. Doctor of Veterinary Medicine (DVM).

39. Abo-Shehada M, Jabreen E, Arab B, Mukbel R, Toergerson P (2002) Prevalence of Taenia multiceps in sheep in northern Jordan. Preventive Veterinary Medicine 55: 201 - 207. Link: https://bit.ly/3DUippm

40. Scala A, Cancedda G, Varcasia A, Ligios C, Garippa G, et al. (2007) A survey of Taenia multiceps coenurosis in Sardinian sheep. Vet Parasitol 143: 294-298. Link: https://bit.ly/3ndCAYw

41. Gemmell MA, Lawson JR, Roberts MG (1987) Population dynamics in echinococcosis and cysticercosis: evaluation of the biological parameters of Taenia hydatigena and Taenia ovis and comparision with those of Echinococcus granulosus. Parasitology 94: 161-180. Link: https://bit.ly/3nc4wf

42. Oryan A, Akbari M, Moazeni M, Amrabadi O (2014) Cerebral and noncerebral coenurosis in small ruminants Trop Biomed 31: 1-16. Link: https://bit.ly/3ncJ9KW

43. Varcasia A, Tosciri G, Coccone G, Pipia A, Garippa G, et al. (2009). Preliminary field trial of a vaccine against coenurosis caused by Taenia multiceps. Vet Parasitol 162: 285-289. Link: https://bit.ly/3AYGJVI

44. Acha P, Szyfres B (2003) Helminthiases: Cestodiases, Text book of zoonoses and communicable diseases common to man and animals

45. Afonso S, Mukaratirwa S, Hajovska K, Capece B, Crist'ofol C, et al. (2011) Prevalence and morphological characteristics of Taenia multiceps Cysts from Abattoir-Slaughtered and Experimentally Infected Goats. Journal of Neuroparasitology 2: 1 - 5. Link: https://bit.ly/3aVUCJ4

46. Alemu S, Kemal J, Mukta Y, Terefe G (2015) Immunological and Molecula Diagnostic Tests for Cestodes and Metacestodes: Review. Journal of World Applied Science 33: 1867-1879. Link: https://bit.ly/3IVq7t1

47. Balseiro A, Royo L, Martínez C, de Mera I, Höfle U, et al. (2012) Louping ill in goats, Spain, 2011. Emerging Infectous Disease 18: 976. Link: https://bit.ly/2XtLJmZ

48. Bechelli K (2005) Parasite project.

49. Benifla M, Barrelly R, Shelef I (2007) Huge hemispheric intraparenchymal cyst caused by Taenia multiceps in a child Case report. Journal of Neurosurg 107: 511-514. Link: https://bit.ly/2Z8j1IE

50. Biswas D (2013) Ultrasound diagnosis and surgical treatment of coenurosis (GID) in bengal goat (Capra hircus) atchittagong metropolitan area, Chittagong, Bangladesh. Journal Veterinary Science 2: 68-75. Link: https://bit.ly/3pfU35m

51. Brumpt E (1913) Veterinary parasitology. $2^{\text {nd }}$ edition, Masson and Co, Paris.

52. Clapham P, Peters B (1941) The differentiation of Coenurus species by hook measurements. Journal Helminthology 19:75-84. Link: https://bit.ly/3G3Y6Y

53. Cluver E, Craig C (1943) Clinical Parasitology, $3^{\text {rd }}$ edition. Lea and Febiger, Philadelphia, PA

54. Correa F, Ferriolli F, Forjaz S (1962) Cerebral coenurosis. Apropos of a human case. Review, Inst Medical Tropical Sao Paulo 4: 38-45. Link: https://bit.ly/3AYG2vd

55. Daoud I, Herbert I (1982) Isolation of two lipoprotein antigens from metacestodes of teania hydatigena( pallas 1766 and teania multiceps(leskes 1780) and there in evaluation in serology. Link: https://bit.ly/2Z7mwiQ

56. Dhaliwal S, Julal P (2013) Text book of parasite zoonosis, Springer India. diagnosis, Veterinary Parasitology 11: 155-164. Link: https://bit.ly/3C3EvoQ

57. Desouky A, Badawy A, Refaat A (2011) Survey on coenurosis in sheep and goats in Egypt. Italiana Veterinarian 47: 333-340. Link: https://bit.ly/3FWf9eS
58. El-Din M (2010) The significance of subarachnoid cerebrospinal fluids (CSF) in the development of metacestode of Coenuruscerebralis in sheep with reference to its pathological effect. Global Veterinary 4: 343-348. Link: https://bit.ly/3pkhsCS

59. El-On J, Shelef I, Cagnano E, Benifla M (2008) Taenia multiceps: a rare human cestode infection in Israel. Veterinaria Italiana 44: 621 - 631. Link: https://bit.ly/3ngpKJk

60. Fentahun T, Fresebehat A (2012) Listeriosis in small ruminants: a Review Advanced Biology Research 6: 202-209. Link: https://bit.ly/3pjncfT

61. Giadinis N, Psychas V, Polizopoulou Z, Papadopoulos E, Papaioannou N, et al. (2012) Acute coenurosis of dairy sheep from 11 flocks in Greece. New Zealand Veterinary Journal 60: 247 - 253. Link: https://bit.ly/3AXPfUt

62. Gauci C, Vural G, Oncel T, Varcasia A, Damian V, et al. (2008) Vaccination with recombinant oncosphere antigens reduces the susceptibility of sheep to infection with Taenia multiceps. International Journal for Parasitology 38 : 1041-1050. Link: https://bit.ly/3vAi5sT

63. Haridy M, Sakai E, El-Shayma E, Ahmed M, Anwar S, et al. (2013) Coenurus cerebralis cysts in the left lateral cerebral ventricle of ewe. J Vet Med Sci 75 1643-1646. Link: https://bit.ly/3DWLG2B

64. Haitchi G, Buchroithner M, Sonnberger S, Weis F, Fellner A (2012) Armed Forces Institute of Pathology best cases in radiologic-pathologic correlation:human coenurosis (Taenia Larva). Radiographics 32: 517-521. Link: https://bit.ly/3Cd6qmx

65. Ioannidou E, Psalla D, Papadopoulos E, Diakou A, Papanikolopoulou V, et al. (2015) Regurgitations in a Lamb with Acute CoenurosisA Case Report. Iran J Parasitol 10: 301-305. Link: https://bit.ly/3AXcQ7Q

66. Johnstone $\mathrm{H}$ and Jones W (1950) Cerebral coenurosis in an infant. Am J Trop Med Hyg 30: 431-441. Link: https://bit.ly/3nakF51

67. Karshima N (2012) A multidisciplinary approach in the control of zoonoses in Nigeria. J Vet Adv 2: 557-567. Link: https://bit.ly/3jjCHAO

68. Kish G, Khodakaram K, Hajimohammadi A, Ahmadi N (2015) Clinica and morpho pathological characteristics of an enzootic occurrence of acute coenurosisin a sheep herd. J Parasit Dis 39: 280-283. Link: https://bit.ly/3IV2Bwi

69. Koumneon A, Argyroundis S, Giedinis N, Dessiris A (2000) Surgical treatment of coenurosis in sheep. Vet Rec 147: 242-244. Link: https://bit.ly/30JC3Gk

70. Lescano A, Zunt J (2013) Other cestodes sparganosis, coenurosis and Taenia crassiceps cysticercosis. Handb Clin Neurol 114: 335-345. Link: https://bit.ly/3aTENCN

71. Mahadevan A, Dwarakanath S, Pai S (2011) Cerebral coenurosis mimicking hydatid disease - report of two cases from South India. Clin Neuropathol 30: 28-32. Link: https://bit.ly/3jjhkzn

72. Mandal S (2006) Veterinary parasitological at glance, first edition, Internationa Book Distributing Company 201-203. Link: https://bit.ly/3DUsqTu

73. Michal A, Regli F, Campiche R, Cavallo R, Crousaz G, et al. (1977) Cerebra coenurosis. Report of a case with arteritis. J Neurol 216: 265-272. Link: https://bit.ly/2Z3yY3z

74. Malomo A, Ogunniyi J, Ogunniyi A (1990) Coenurosis of the centra nervous system in a Nigerian. Tropical Georgia Medical 42: 280-282. Link: https://bit.ly/3vvrlsF

75. Murell K (2005) Epidemiology of Taeniosis and Cysticercosis. Guidelines for the Surveillance, Prevention and Control of Taeniosis/Cysticercosis, WHO/ FAO/OIE, Paris 44.

76. Neni S (2012) Study on the prevalence and economic implication of coenurus cerbrallis in sheep and goat in and around Yabello district of Borena zone.

Citation: Diba S, Garoma A (2021) Epidemiology and economic loss of coenurosis in small Ruminants slaughtered at mojo halal export abattoir, Oromia reginal state, East Shoa Zone, Ethiopia. Int J Vet Sci Res 7(2): 127-137. DOI: https://dx.doi.org/10.17352/ijvsr.000092 
Jimma university, college of Agriculture and veterinary Medicine, DVM, Thesis (URL) 31 .

77. Nourani H, Kheirabadi K (2009) Cerebral coenurosis in a goat: Pathological findings and literature review. Company of Clinical Pathology 18: 85-87. Link: https://bit.ly/3G2Cr2Y

78. Oge H, Oge B, Gonenc G, Ozbakis C (2012) Coenurosis in the lumbar region of a goat. Veterinary Medicine 57: 308-313. Link: https://bit.ly/3vrjvGa

79. Oryan A, Moazeni O, Amrabadi M, Akbari H, Sharifiyazdi N (2015) Comparison of distribution pattern, pathogenesis and molecular characteristics of larval stages of Taeniamulticeps in sheep and goats. Small Ruminant Research 132 44-49. Link: https://bit.ly/30JQMRF

80. Özkan C, Yildirim S, Kaya A (2011) Clinical coenurosis (Coenurus cerebralis) and associated Pathological findings in acalf. Pakistan Veterinary Journal 31 263-266. Link: https://bit.ly/3G0FpEZ

81. Pau A, Turtas S (1987) Computed tomography and magnetic resonance imaging of cerebral coenurosis. Surg Neurol 27: 548-552. Link: https://bit.ly/3DWLsIN

82. Radostits O, Gay C, Blood D, Hinchcliff K (2000) Veterinary Medicine. A Textbook of the disease of cattle, sheep, pigs, goats and horse. ( $10^{\text {th }}$ edition), Saunders, London, United Kingdom 1583.
83. Rostami S, Beech R, Salavati M, Baneshi H, Kamyabi M, et al. (2013) Morphometric analysis of larval rostellar hooks in Taenia multiceps of sheep in Iran and its association with mitochondrial gene variability. Iranian Journal of Parasitology 8: 579-585. Link: https://bit.ly/3aUCmzW

84. Scala A, Varcasia A (2006) Updates on morphobiology, Epidemiology and molecular characterization of coenurosis in sheep. Veterinary Parassitology 48: 61-63. Link: https://bit.ly/3n9m8bZ

85. Thrusfield M (2005) Veterinary Epidemiology, (2 ${ }^{\text {nd }}$ edition). Blackwell Science, USA 182-198.

86. Uslu U, Guclu F (2007) Prevalence of Coenurus cerbralis in th sheep in Turkey. Medycyna Wet 63: 678680. Link: https://bit.ly/3pfWzbO

87. Varcasia A, Jia W, Yan H, Manunta M, Pipia A, et al. (2012) Molecular characterization of subcutaneous and muscular coenurosis of goats in United Arab Emirates. Vet Parasitol 190: 604-60. Link: https://bit.ly/3FZGehv

88. Wang Y, Nie H, Gu X, Wang X, Chen L, et al. (2015) An ELSIA using recombinant TmHSP70 for the diagnosis for Teania multiceps infections in goats. Vet Parasitol 212: 469-472. Link: https://bit.ly/3aTbC2D

89. Wu X, Fu Y, Yang D, Zhang R, Zhang W, et al. (2012) Detailed characterization of $\mathrm{T}$. madoqueanf $\mathrm{T}$. regis from carnivores in Kenya using markers in nuclear mitochondrial DNA, and others relationship with other selected taenids, molecular and cellular probes 21: 379-385

\section{Discover a bigger Impact and Visibility of your article publication with}

\section{Peertechz Publications}

\section{Highlights}

* Signatory publisher of ORCID

* Signatory Publisher of DORA (San Francisco Declaration on Research Assessment)

* Articles archived in worlds' renowned service providers such as Portico, CNKI, AGRIS, TDNet, Base (Bielefeld University Library), CrossRef, Scilit, J-Gate etc.

* Journals indexed in ICMJE, SHERPA/ROMEO, Google Scholar etc.

* OAI-PMH (Open Archives Initiative Protocol for Metadata Harvesting)

* Dedicated Editorial Board for every journal

* Accurate and rapid peer-review process

* Increased citations of published articles through promotions

- Reduced timeline for article publication

Submit your articles and experience a new surge in publication services (https://www.peertechz.com/submission).

Peertechz journals wishes everlasting success in your every endeavours. 